\title{
NATURAL DURABILITY OF Eucalyptus dunnii Maiden, Eucalyptus robusta Sm., Eucalyptus tereticornis Sm. AND Hovenia dulcis Thunb. WOOD IN FIELD AND FOREST ENVIRONMENT ${ }^{1}$
}

\author{
Douglas Edson Carvalho ${ }^{2 *}$, Ana Paula Marques Martins², Elio José Santini ${ }^{3}$, Liana Sarturi de Freitas ${ }^{4}$, \\ Maiara Talgatti ${ }^{5}$ and Felipe Susin ${ }^{5}$
}

\footnotetext{
${ }^{1}$ Received on 30.06.2015 accepted for publication on 03.12.2015.

${ }^{2}$ Universidade Federal do Paraná, Programa de Pós-graduação em Engenharia Florestal, Curitiba, PR - Brasil. E-mail: <douglasedsoncarvalho@gmail.com>and<anapaula_marquesm@yahoo.com.br>.

${ }^{3}$ Universidade Federal de Santa Maria, Departamento de Ciências Florestais, Santa Maria, RS - Brasil. E-mail: <ejsantini@gmail.com>. ${ }^{4}$ Universidade Federal de Santa Maria, Graduado em Engenharia Florestal, Santa Maria, RS - Brasil. E-mail: <liana_sarturi@hotmail.com>. ${ }^{5}$ Universidade Federal de Santa Maria, Programa de Pós-Graduação em Engenharia Florestal, Santa Maria, RS - Brasil. Email:<maiara.talgatti@gmail.com>and<felipets_86@yahoo.com.br>.
}

${ }^{*}$ Corresponding author.

\begin{abstract}
This study aimed at evaluating the natural durability of Eucalyptus dunnii, Eucalyptus robusta, Eucalyptus tereticornis and Hovenia dulcis woods submitted to a deterioration test in two environments, field and forest. The test samples were buried until half of their length $(150 \mathrm{~mm})$. Evaluations were carried out each 45 days, totalizing a 405-day period, with three-repetition withdrawal of each species for environment, totalizing nine samples from each environment, making up 24 test samples for evaluation. After percentage calculations of mass loss and resistance degree classification, the deterioration index was adopted for decomposition evaluation and fungal decay potential determination of test samples. The study has been carried out in completely randomized design (CRD), evaluated through analysis of variance (ANOVA) with subsequent comparison of means by Turkey's test, in a 5\%-level of probability of error, along with regression analysis. Eucalyptus tereticornis wood presented lesser mass loss in both environments. Hovenia dulcis presented lesser deterioration probability in both environments. Forest environment test samples presented greater mass loss percentages and lesser deterioration index.
\end{abstract}

Keywords: Mass loss; Deterioration index; Fungal decay potential.

\section{DURABILIDADE NATURAL DE MADEIRA DE Eucalyptus dunnii Maiden, Eucalyptus robusta Sm., Eucalyptus tereticornis Sm. E Hovenia dulcis Thunb. EM AMBIENTE DE CAMPO E FLORESTA}

\begin{abstract}
RESUMO - O estudo teve como objetivo avaliar a durabilidade natural das madeiras de Eucalyptus dunnii, Eucalyptus robusta, Eucalyptus tereticornis e Hovenia dulcis submetidas a ensaio de deterioração em dois ambientes, campo efloresta. Os corpos de prova foram enterrados até metade de seu comprimento (150 $\mathrm{mm}$ ). As avaliações foram feitas a cada 45 dias, totalizando um período de 405 dias, com retirada de três repetições de cada espécie por ambiente, totalizando nove amostras de cada ambiente, perfazendo 24 corpos de prova por avaliação. Após calculadas as porcentagens de perda de massa e classificadas quanto ao grau de resistência, adotou-se o índice de deterioração para avaliação da decomposição dos corpos de prova e determinação do potencial de ataque fúngico. O estudo foi conduzido em delineamento inteiramente casualizado (DIC), avaliados por análise de variância (ANOVA), com posterior comparação de média pelo teste de Tukey, em nivel de 5\% de probabilidade de erro, juntamente com análise de regressão. A madeira de Eucalyptus tereticornis apresentou menor perda de massa em ambos os ambientes. A madeira de Hovenia dulcis apresentou menor probabilidade de deterioração em ambos os ambientes. Os corpos de prova do ambiente de floresta apresentam maiores percentuais de perda de massa e menor índice de deterioração.
\end{abstract}

Palavras-chave: Perda de massa; Índice de deterioração; Potencial de ataque fúngico. 


\section{INTRODUCTION}

The use of wood in contact with soil depends on external agents resistance that can cause wood damage and consequently interfere in its durability. Costa (2003) states that among the different wood properties, the natural deterioration resistance stands out, which is the species, intrinsic ability to resist the action of spoilage agents, referring to the mechanical, physical, chemical and biological ones. However, Willeitner (1984) states that because of economic value, natural resistance is normally seen as referring to biological agents.

According to Oliveira (1997), some particular wood will have preference for use in relation to others when its natural durability is longer, because if we avoid inconveniences arising from the use of chemical products, some very toxic, utilized in the treatment of low durability wood in order to provide it with a satisfactory performance in service. Besides environmental restrictions to the products that currently dominate preserving industry, some technical aspects related to the wood itself to be preserved are relevant. Such aspects are related to resistance to impregnation of wood from certain species, as in the case of eucalyptus heartwood. Cookson (2000) confirmed the difficulty penetration by preservatives in eucalyptus heartwood, proving the great importance of choosing species from this genus that have some natural durability to xylophagous organisms.

Oliveira et al. (1986) affirmed that temperature, humidity and precipitation conditions are important in the determination of microorganisms capable of invading wood and decay it and these conditions have great impact over decomposition rate and other factors related to wood. According to Santini's statement (1988), the content of parenchyma cells of certain species like starches, proteins and sugars, etc., are very sought by fungi and insects as food, which explains its greater susceptibility to attack. Under favorable humidity, temperature and $\mathrm{pH}$ conditions, all woods become susceptible to attack by xylphagous organisms (TEXEIRA, et al. 1997).

In the face of this situation, the present study aimed at evaluating the natural durability of Eucalyptus dunnii, Eucalyptus robusta, Eucalyptus tereticornis and Hovenia dulcis woods, submitted to a deterioration test in two environments, field and forest.

\section{MATERIALAND METHODS}

In order to carry out the present study, the Eucalyptus dunnii Maiden, Eucalyptus robusta Sm, Eucalyptus tereticornis $\mathrm{Sm}$ and Hovenia dulcis Thunberg heartwoods, approximately aged 35 , have been used. The wood samples were originally from the Fundação Estadual de Pesquisa Agropecuária-Centro de Pesquisa em Recursos Florestais (State Foundation of Agricultural Research - Research Center in Forest Resources) (FEPAGRO FLORESTAS), located at the District of Boca do Monte in the City of Santa Maria, RS. Test samples, with dimensions of $20 \times 20 \times 300$ $\mathrm{mm}$ in thickness, width and length, respectively, have been made for the tests. Defect-free test samples have been selected, such as no wane presence, cracks and knots.

The apparent wood mass in $12 \%$ of humidity has been determined from mass and volume of samples taken after stabilization of their equilibrium humidity in climate chamber at the temperature of $20 \pm 2^{\circ} \mathrm{C}$ and relative humidity of $65 \pm 5 \%$.

The dry mass of each sample has been determined with the assistance of a $0,01 \mathrm{~g}$ precision electronic scale. The samples have been buried until half of their length $(150 \mathrm{~mm})$ in environments of open field and forest. Evaluations have been conducted each 45 days, totalizing a 405-day period, with three-repetition withdrawal of each species for environment, totalizing nine samples from each environment, making up 24 test samples for evaluation. After each collection, the material has gone through a cleansing process for aggregated soil removal from samples with the assistance of a brush. Then, the material has been taken again to the greenhouse at the temperature of $103^{\circ} \mathrm{C}$ for dry mass obtainment and, through the difference between the initial and final dry mass, the mass loss has been achieved and the material was classified in resistance classes according to the norm ASTMD-2017(ASTM, 2005).

Besides being classified as for its resistance, the deterioration index adapted by Lepage et al. (1986) has been adopted for evaluation of decomposition in test samples where, through damage cause on them, notes have been assigned to the generation of the deterioration average index.

Complementarily, climate information on the site has been obtained, as maximum, minimum and average daily temperature, precipitation and relative humidity 
during the whole experiment period. Based on climate information, it was possible to determine fungal decay potential (FDP), estimated index (Equation 1), initially developed by Scheffer (1971) and adapted to Brazil by Martins et al. (2003). The FDP estimates the risk of incidence by decay fungi due to two important environmental variables for the development of these xylophagous agents, temperature and precipitation.

$$
F D P=\sum \frac{[(T-2)] *[(D-3)]}{16,7}
$$

In which: $F D P=$ Fungal Decay Potential; $T=$ average temperature $\left({ }^{\circ} \mathrm{C}\right) ; D=$ number of days in month with precipitation equal to or greater than $0.3 \mathrm{~mm}$.

In order to complement, soil collection at two experiment environments and a subsequent analysis at the Department of Soil at the Federal University of Santa Maria (UFSM) have been carried out, aiming at the determination of mineral and organic constituents. The study has been conducted in completely randomized design (CRD), evaluated through analysis of variance (ANOVA) with subsequent comparison of means by Turkey's test, in a 5\%-level of probability of error, along with simple linear regression analysis (Equation 2). All statistical analyses have been carried out with the assistance of Statgraphics Centurion XV.II software program.

$$
\hat{y}=b_{0}+b_{1} t+e
$$

In which: $\hat{y}=$ dependent variable (mass loss $\%$ or deterioration index $) ; t=$ time in days $; e=$ random error.

\section{RESULTS}

\subsection{Soil analysis and climate conditions}

Regarding the soil acidity diagnosis, the $\mathrm{pH}$ from both environments were similar, 4,5 and 4,9 for forest and field, respectively. The diagnosis for macronutrients pointed out that the forest soil had higher organic matter content, $3,3 \%$, whereas the amount found in field was $1,9 \%$. This indicates that the forest soil presented a higher propensity for the development of xylophagous microorganisms.
Figure 1 presents the relative humidity variation, the average temperature, the fungal decay potential and the number of days with precipitation equal to or higher than $0,30 \mathrm{~mm}$. It is possible to observe the relative humidity variation during the 405 days of experiment. It can be noted that relative humidity values oscillated between $69,9 \%$ and $79,6 \%$. The average temperature oscillation was $14,4{ }^{\circ} \mathrm{C}$, in the month of July, to $27,8^{\circ} \mathrm{C}$, in the month of March.

\subsection{Specific mass, mass loss and deterioration index}

Given the values for specific mass obtained in the study, the species Hovenia dulcis $\left(0,66 \mathrm{~g} / \mathrm{cm}^{3}\right)$ and Eucalyptus robusta $\left(0,75 \mathrm{~g} / \mathrm{cm}^{3}\right)$ can be classified as moderately heavy density woods, situated between 0,65 and $0,79 \mathrm{~g} / \mathrm{cm}^{3}$. Meanwhile, Eucalyptus dunnii $(0,88$ $\left.\mathrm{g} / \mathrm{cm}^{3}\right)$ and Eucalyptus tereticornis $\left(0,90 \mathrm{~g} / \mathrm{cm}^{3}\right) \mathrm{can}$ be classified as heavy woods, as light to dark heartwood eucalyptus, with densities between 0,80 and $0,95 \mathrm{~g} /$ $\mathrm{cm}^{3}$, according to Carvalho's classification (1996). A direct relation can be observed between specific mass and mass loss of species, with some variations.

Table 1 presents mass loss values of the species studied for field and forest environments due to time in days exposed to the decaying field. It can be noted that mass loss mostly increased along with exposure time of test samples.

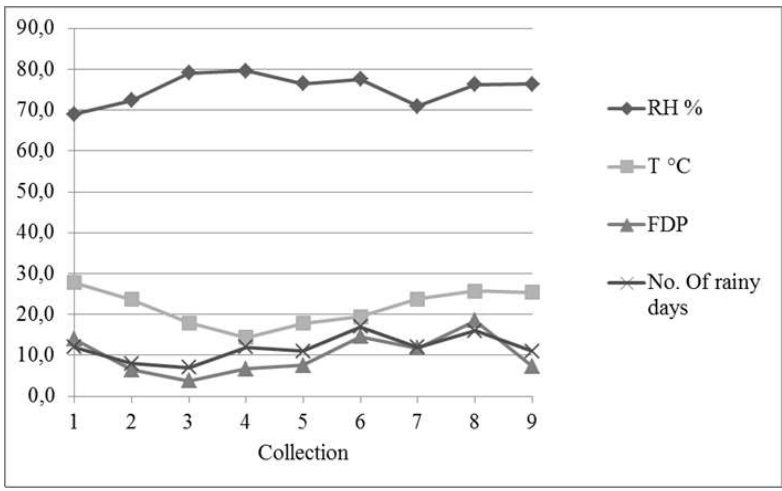

Figure 1 - Relative Humidity Variation (RH \%); Temperature $\left(\mathrm{T}^{\circ} \mathrm{C}\right)$; Fungal Decay Potential (FDP) and No. of days with rain equal or higher than $0,30 \mathrm{~mm}$ during the experiment.

Figuras 1 - Variação da Umidade Relativa (UR\%); Temperatura $\left(T^{\circ} \mathrm{C}\right)$; Potencial de Ataque Fúngico (PAF) e Número de dias com chuva igual ou superior a $0,30 \mathrm{~mm}$ durante o experimento.

Revista Árvore, Viçosa-MG, v.40, n.2, p.363-370, 2016 
Table 1 - Mass Loss (\%) of species submitted to decaying field.

Tabela 1 - Perda de Massa (\%) das espécies submetidas ao campo de apodrecimento.

\begin{tabular}{|c|c|c|c|c|c|c|c|c|c|}
\hline \multirow[t]{2}{*}{ Collection } & \multirow[t]{2}{*}{ Days } & \multicolumn{2}{|c|}{ E. tereticornis } & \multicolumn{2}{|c|}{ H. dulcis } & \multicolumn{2}{|c|}{ E. robusta } & \multicolumn{2}{|c|}{ E. dunnii } \\
\hline & & Field & Forest & Field & Forest & Field & Forest & Field & Forest \\
\hline 1 & 45 & 7,8 & 7,6 & 11,0 & 11,7 & 12,6 & 12,8 & 9,0 & 9,0 \\
\hline 2 & 90 & 8,4 & 10,8 & 13,3 & 10,9 & 13,0 & 11,7 & 11,1 & 15,6 \\
\hline 3 & 135 & 9,2 & 14,4 & 13,4 & 12,8 & 13,1 & 13,8 & 14,7 & 20,2 \\
\hline 4 & 180 & 15,1 & 13,9 & 11,9 & 12,6 & 12,5 & 13,1 & 11,1 & 24,8 \\
\hline 5 & 225 & 11,8 & 22,7 & 13,0 & 14,4 & 12,9 & 14,1 & 11,6 & 21,5 \\
\hline 6 & 270 & 7,1 & 14,1 & 15,3 & 15,8 & 13,1 & 14,2 & 13,3 & 22,8 \\
\hline 7 & 315 & 6,0 & 20,8 & 18,8 & 18,0 & 13,7 & 16,5 & 14,1 & 31,1 \\
\hline 8 & 360 & 7,4 & 21,9 & 14,4 & 22,8 & 13,9 & 19,8 & 19,0 & 43,1 \\
\hline 9 & 405 & 18,5 & 13,0 & 17,4 & 27,5 & 14,4 & 27,1 & 15,2 & 46,2 \\
\hline \multicolumn{2}{|c|}{ Average } & 10,14 & 15,47 & 14,28 & 16,28 & 13,24 & 15,90 & 13,23 & 26,03 \\
\hline
\end{tabular}

Results from the forest environment presented a higher mass loss tendency in relation to the open field environment, which can be explained by more adequate conditions for the development of wood biodeterioration agents, as previously mentioned, due to the microclimate present in the forest.

According to the norm ASTMD-2017 (2005), results from Eucalyptus tereticornis field and forest environments were classified as very resistant to resistant. For Hovenia dulcis, results from field were classified as resistant, as well as in forest, carrying out the value of the last collection, classified as moderately resistant. A similar behavior has also been observed in Eucalyptus robusta, with small variations in values obtained. Eucalyptus dunnii was classified as resistant for field environment, whereas for forest, it was classified as resistant to moderately resistant wood, with the last collection being classified as non-resistant. Resistance variation has occurred due to material exposure time at the decaying field and consequent susceptibility to attack by xylophagous organisms.

The state of sanity of the species studied has been analyzed by the deterioration index, submitted to open field and forest environments, whose values can be observed in Table 2. It can be verified that the highest indices were in the first collections, tending to decrease along with exposure time, with some oscillations between collections. These highest values indicate lesser probability of attacks.

It can be observed that the values for the deterioration index tended to be more reduced in forest environment, presenting a higher degradation than samples from open field.

In Table 3, it can be observed that the comparative average values among species and environment, species, environment and evaluations. For the evaluation of species and environment, it can be noted that mass loss inversely varied in relation to the specific mass

Table 2 - Deterioration Index of species submitted to decaying field.

Tabela 2 -Índice de deterioração das espécies submetidas a campo de apodrecimento.

\begin{tabular}{|c|c|c|c|c|c|c|c|c|c|}
\hline \multirow[t]{2}{*}{ Collection } & \multirow[t]{2}{*}{ Days } & \multicolumn{2}{|c|}{ E. tereticornis } & \multicolumn{2}{|c|}{ H. dulcis } & \multicolumn{2}{|c|}{ E. robusta } & \multicolumn{2}{|c|}{ E. dunnii } \\
\hline & & Field & Forest & Field & Forest & Field & Forest & Field & Forest \\
\hline 1 & 45 & 93,3 & 86,7 & 100,0 & 93,3 & 100,0 & 90,0 & 90,0 & 76,7 \\
\hline 2 & 90 & 80,0 & 70,0 & 93,3 & 93,3 & 90,0 & 90,0 & 90,0 & 43,3 \\
\hline 3 & 135 & 76,7 & 76,7 & 90,0 & 93,3 & 83,3 & 76,7 & 70,0 & 26,7 \\
\hline 4 & 180 & 90,0 & 50,0 & 96,7 & 96,7 & 83,3 & 70,0 & 70,0 & 13,3 \\
\hline 5 & 225 & 90,0 & 50,0 & 90,0 & 93,3 & 90,0 & 76,7 & 40,0 & 83,3 \\
\hline 6 & 270 & 90,0 & 70,0 & 83,3 & 76,7 & 83,3 & 90,0 & 76,7 & 26,7 \\
\hline 7 & 315 & 90,0 & 50,0 & 90,0 & 60,0 & 90,0 & 70,0 & 70,0 & 0,0 \\
\hline 8 & 360 & 70,0 & 36,7 & 90,0 & 60,0 & 90,0 & 70,0 & 50,0 & 0,0 \\
\hline 9 & 405 & 70,0 & 0,0 & 83,3 & 13,3 & 13,3 & 60,0 & 26,7 & 0,0 \\
\hline Aver & & 83,33 & 54,46 & 90,73 & 75,54 & 80,36 & 77,04 & 64,82 & 30,0 \\
\hline
\end{tabular}

Revista Árvore, Viçosa-MG, v.40, n.2, p.363-370, 2016 
of species in field environment, whereas, in forest environment, the same behavior was not noticed only for Eucalyptus dunnii, because it presented more likely to mass loss. By analyzing the values of field environment, it can be verified that Eucalyptus tereticornis presented the lowest average mass loss, statistically differing from the other species, which did not differ among themselves. In forest environment, Eucalyptus dunnii statistically differed from the other species, presenting the highest mass loss.

By analyzing the difference between environments, it can be noted that the species Hovenia dulcis did not present statistical difference between open field and forest. It can still be perceived that the forest environment presented higher mass loss than field environment for all species.

As for the deterioration index, it can be perceived that the species Eucalyptus dunnii presented higher probability to attack by biodeterioration agents, statistically differing from the other species. The species Eucalyptus tereticornis did not statistically differ from Eucalyptus robusta, but the latter presented difference in relation to Hovenia dulcis. A similar behavior has been observed in forest environment, but in this environment, Eucalyptus tereticornis and Eucalyptus robusta differed between themselves.

As for species, it can be noted that the species Eucalyptus dunnii proved to be more likely for both deterioration index and mass loss, differing from the other species. As for environment analysis, it can be perceived that there has been statistical difference between them, with wood from forest environment being more affected for both deterioration index and mass loss. As for the evaluations carried out accordingly to time in days, a deterioration index decrease and mass loss increase with the growth of exposure time is perceived. These facts indicate that the deterioration index along with mass loss are safe methods for the evaluation of species natural durability and indicate the attack by biodeterioration agents to wood.

In Table 4, linear equations adjusted for deterioration index and mass loss estimation from the woods studied can be observed, accordingly to the time in which samples remained exposed to environments.

Table 3 - Comparison of Averages for deterioration index and mass loss in relation to species, environments and evaluations. Tabela 3 - Comparação de médias para o índice de deterioração e perda de massa em função das espécies, ambientes e avaliações.

\begin{tabular}{|c|c|c|c|c|}
\hline \multirow[t]{2}{*}{ Species } & \multicolumn{2}{|c|}{ Mass loss $(\%)$} & \multicolumn{2}{|c|}{ Deterioration index } \\
\hline & Field & Forest & Field & Forest \\
\hline Eucalyptus tereticornis & $10,1 \mathrm{~A} \mathrm{a}$ & $15,5 \mathrm{~A} \mathrm{~b}$ & $83,3 \mathrm{~B}$ a & $54,4 \mathrm{~B} \mathrm{~b}$ \\
\hline Eucalyptus dunnii & $13,2 \mathrm{~B}$ a & $26,0 \mathrm{~B} \mathrm{~b}$ & $64,8 \mathrm{~A} \mathrm{a}$ & $30,0 \mathrm{~A} \mathrm{~b}$ \\
\hline Eucalyptus robusta & $13,3 \mathrm{~B} \mathrm{a}$ & $15,9 \mathrm{~A} \mathrm{~b}$ & $88,9 \mathrm{BC} \mathrm{a}$ & $71,1 \mathrm{C} \mathrm{b}$ \\
\hline Hovenia dulcis & $14,3 \mathrm{~B} \mathrm{a}$ & $16,3 \mathrm{~A} \mathrm{a}$ & $90,7 \mathrm{C} \mathrm{a}$ & $75,6 \mathrm{C} \mathrm{b}$ \\
\hline Species & \multicolumn{2}{|c|}{ Mass loss (\%) } & \multicolumn{2}{|c|}{ Deterioration index } \\
\hline Eucalyptus dunnii & \multicolumn{2}{|c|}{$19,63 \mathrm{a}$} & \multicolumn{2}{|c|}{$48,15 \mathrm{a}$} \\
\hline Eucalyptus tereticornis & \multicolumn{2}{|c|}{$12,80 \mathrm{~b}$} & \multicolumn{2}{|c|}{$68,89 \mathrm{~b}$} \\
\hline Eucalyptus robusta & \multicolumn{2}{|c|}{$14,57 \mathrm{~b}$} & \multicolumn{2}{|c|}{$81,48 \mathrm{bc}$} \\
\hline Hovenia dulcis & \multicolumn{2}{|c|}{$15,28 \mathrm{~b}$} & \multicolumn{2}{|c|}{$84,63 \mathrm{c}$} \\
\hline Environment & \multicolumn{2}{|c|}{ Deterioration index } & \multicolumn{2}{|c|}{ Mass loss (\%) } \\
\hline Forest & \multicolumn{2}{|c|}{$59,26 \mathrm{a}$} & \multicolumn{2}{|c|}{18,42 a } \\
\hline Field & \multicolumn{2}{|c|}{$82,31 \mathrm{~b}$} & \multicolumn{2}{|c|}{$12,73 \mathrm{~b}$} \\
\hline Evaluations (days) & \multicolumn{2}{|c|}{ Deterioration index } & \multicolumn{2}{|c|}{ Mass loss (\%) } \\
\hline $1(45)$ & \multicolumn{2}{|c|}{$92,08 \mathrm{a}$} & \multicolumn{2}{|c|}{$10,19 \mathrm{a}$} \\
\hline $2(90)$ & \multicolumn{2}{|c|}{$80,42 \mathrm{ab}$} & \multicolumn{2}{|c|}{$11,85 \mathrm{ab}$} \\
\hline $3(135)$ & \multicolumn{2}{|c|}{$73,75 \mathrm{ab}$} & \multicolumn{2}{|c|}{$13,96 \mathrm{ab}$} \\
\hline $4(180)$ & \multicolumn{2}{|c|}{$72,08 \mathrm{ab}$} & \multicolumn{2}{|c|}{$14,38 \mathrm{abc}$} \\
\hline $5(225)$ & \multicolumn{2}{|c|}{$79,17 \mathrm{ab}$} & \multicolumn{2}{|c|}{$15,27 a b c$} \\
\hline $6(270)$ & \multicolumn{2}{|c|}{$72,92 \mathrm{ab}$} & \multicolumn{2}{|c|}{$14,47 \mathrm{abc}$} \\
\hline $7(315)$ & \multicolumn{2}{|c|}{$65,00 \mathrm{bc}$} & \multicolumn{2}{|c|}{$17,37 \mathrm{bcd}$} \\
\hline $8(360)$ & & & & \\
\hline $9(405)$ & & & & \\
\hline
\end{tabular}

The averages followed by the same letter do not differ statistically (Turkey $\mathrm{p}>0,05$ ). 
Table 4 - Prediction models of Deterioration Index and Mass Loss in relation to exposure time of woods to deterioration tests in field and forest.

Table 4 - Modelos de predição do Índice de Deterioração e Perda de Massa em função do tempo de exposição das madeiras aos ensaios de deterioração em campo aberto e floresta.

\begin{tabular}{|c|c|c|c|c|c|c|}
\hline \multicolumn{7}{|c|}{ DETERIORATION INDEX } \\
\hline Species & Environment & $B_{0}$ & $B_{1}$ & $R_{a j}^{2}(\%)$ & $S_{y x}(\%)$ & $F$ \\
\hline \multirow[t]{2}{*}{$\overline{\text { Eucalyptus dunnii }}$} & Field & 95,5556 & $-0,13333$ & 44,6 & 17,19 & $21,93 *$ \\
\hline & Forest & 70,463 & $-0,176543$ & 30,36 & 30,35 & $12,34 *$ \\
\hline \multirow[t]{2}{*}{ Eucalyptus robusta } & Field & 24,5712 & $-0,0246878$ & 12,82 & 6,79 & $4,82 *$ \\
\hline & Forest & 87,037 & $-0,054321$ & 28,20 & 9,79 & $11,21 *$ \\
\hline \multirow[t]{2}{*}{ Hovenia dulcis } & Field & 28,5354 & $-0,0334145$ & 33,37 & 5,39 & $14,02 *$ \\
\hline & Forest & 115,926 & - 0,153086 & 70,4 & 11,66 & $62,84^{*}$ \\
\hline \multirow[t]{2}{*}{ Eucalyptus tereticornis } & Field & 93,2407 & - 0,0407407 & 18,06 & 9,48 & $6,73 *$ \\
\hline & Forest & 94,4444 & - 0,177778 & 52,87 & 19,54 & $30,17 *$ \\
\hline \multicolumn{7}{|c|}{ MASS LOSS } \\
\hline Species & Environment & $B_{0}$ & $B_{1}$ & $R_{a j}^{2}(\%)$ & $S_{y x}(\%)$ & $F$ \\
\hline \multirow[t]{2}{*}{ Eucalyptus dunnii } & Field & 89,8758 & 0,0180183 & 36,84 & 2,71 & $16,17 *$ \\
\hline & Forest & 5,10258 & 0,093002 & 73,26 & 6,60 & $72,25 *$ \\
\hline \multirow[t]{2}{*}{ Eucalyptus robusta } & Field & 12,2897 & 0,00426812 & 66,34 & 0,35 & $52,24 *$ \\
\hline & Forest & 146,048 & 0,0254923 & 54,89 & 2,69 & $32,64 *$ \\
\hline \multirow[t]{2}{*}{ Hovenia dulcis } & Field & 10,7195 & 0,0158873 & 47,68 & 1,93 & $24,70 *$ \\
\hline & Forest & 6,92041 & 0,0415693 & 61,48 & 3,85 & $42,49 *$ \\
\hline \multirow[t]{2}{*}{ Eucalyptus tereticornis } & Field & 8,02051 & 0,00939259 & 0,04 & 5,64 & $1,01^{\mathrm{nm}}$ \\
\hline & Forest & 9,85284 & 0,0249696 & 13,45 & 6,71 & $5,04 *$ \\
\hline
\end{tabular}

In which: $\mathrm{R}^{2} \mathrm{aj}=$ adjusted coefficient of determination; $\operatorname{Syx}(\%)=$ standard error of the estimate; $\mathrm{F}=\mathrm{value}$ of $\mathrm{F}$ calculated; $*=$ meaningful to $5 \%$ of probability.

It can be observed that meaningful equations have been generated for the deterioration index, with higher determination coefficients for forest environment, the same fact did not occur for Eucalyptus dunnii. In equations generated for mass loss, only the field environment equation for Eucalyptus tereticornis was not meaningful, contrasting with the other equations that presented meaningful adjustments. As for Eucalyptus robusta, the determination coefficient was higher in field environment, differing from the other species. Conducting studies aiming at identifying extractives and other chemical compounds that affect wood natural durability is advisable.

\section{DISCUSSIONS}

\subsection{Climate Conditions Analysis}

The number of rainy days followed FDP variation, which presented variations from 3,8 to 18,5 . The collection that presented the highest FDP value was in January, which presented the highest occurrence of rainy days, 16 days, with relative humidity of $76,2 \%$ and temperature of $25,7^{\circ} \mathrm{C}$, confirming Moreschi's statement (1980) that temperatures near $25^{\circ} \mathrm{C}$ represent a higher risk of fungal attack in woods. Just like Silva et al. (2005), who stated that the ideal temperature for most xylophagous organisms is between 20 and $30^{\circ} \mathrm{C}$, similar to what was observed in the study, with average temperature of $21,8^{\circ} \mathrm{C}$ for the whole data collection period.

The lowest FDP value has been found in the collection carried out in June, which was the period with less rainy days, 7 days, with relative humidity of $79,0 \%$ and average temperature of $17,9^{\circ} \mathrm{C}$. The values fund corroborate studies carried out by Trevisan (2006), which affirm that environmental variations, mainly in relation to temperature and humidity, have fundamental importance in the development of microorganisms able to attack and in wood decomposition rate. The same author affirms that microorganism species present different ideal conditions of tolerances to the environment.

\subsection{Specific mass, mass loss and deterioration index}

The deterioration index values in this research corroborate what was found by Trevisan et al. (2008), studying wood behavior from five forest species according to deterioration in two environments (open field and forest), they also found the same tendency, 
with higher mass loss in forest when compared to open field. For Melo et al. (2010), the analysis by attribution of notes is the main parameter for evaluation of wood durability in experiments at decaying fields. However, Lopez and Milano (1986) affirm that various researchers used, besides visual evaluations as the deterioration index, a second parameter, which can be mechanical testing or mass loss, as used in this study, in order to characterize wood natural durability in field experiment.

The forest environment presented a higher mass loss than open field environment for all species. Trevisan et al. (2008) found similar results and attributed the fact to a higher humidity existing in forest environment, which combined with the higher stability of environmental conditions (temperature and humidity) from that place are favorable factors to the higher incidence of termites and coleopterans (beetles) in these environments, when compared to the open field experiment.

In relation to mass loss among species, a lesser mass loss has been found for Eucalyptus tereticornis wood can be explained by the presence of some compounds with fungicide and insecticide action, minimizing wood damage, as stated by Paes et al. (2007), some extractives can be toxic to xylophagous organisms. The inverse behavior is attributed to Eucalyptus dunnii in forest environment that can be explained by the absence of some toxic extractives to biodeterioration organisms, to the highest organic matter content and consequently action by xylophagous agents.

Comparing the environments in which species have been submitted, a meaningful difference can be perceived among all species evaluated, which indicates that deterioration in forest environment was higher than in open field environment, corroborating the statement by Trevisan et al. (2007) that this fact happens because forest provides environmental conditions that benefit the development of biodeterioration organisms.

\section{CONCLUSIONS}

Based on results obtained, it can be concluded that:

The number of rainy days and temperature directly influence the fungal decay potential.

The Eucalyptus tereticornis wood presented a lesser mass loss in both environments.

The Hovenia dulcis wood presented a lesser probability of attack in both environments according to the deterioration index criterion
Test samples from forest environment presented higher percentages of mass loss and lesser deterioration index.

Exposure time considerably affected mass loss and deterioration index in the woods studied.

\section{REFERENCES}

\section{AMERICAN SOCIETY FOR TESTING AND}

MATERIALS - ASTM. ASTM D-2017:

standard method for accelerated laboratory test of natural decay resistance for woods. Philadelphia: 2005.

\author{
CARvalho, A. Madeiras Portuguesas - \\ Estrutura anatômica, propriedades, \\ utilizações. Lisboa: Instituto Florestal, 1996. v. \\ $1.340 \mathrm{p}$
}

COOKSON,L.J.The preservation of eucalypts. In: CONFERENCE OF THE FUTURE OF EUCALYPTS FOR WOOD PRODUCTS,

n.1.,2000,Launceston.Proceedings... Launceston: IUFRO, 2000.p.248-85.

COSTA, A.F. Processos práticos de tratamento de madeiras para o meio rural. Brasília: Universidade de Brasília, 2003. 26 p.

LEPAGE, E.S.;OLIVEIRA, A. M. F.; LELIS, A. T. de; CARBALLEIRA LOPEZ, G. A.; CHIMELO, J. P.; OLIVIEIRA, L. C. S.; CAÑEDO, M. D.; CAVALCANTE, M. S.; IELO, P. K. Y.; ZANOTTO, P. A.; MILANO, S. Manual de preservação de madeiras. São Paulo: IPT - Divisão de Madeiras, 1986.v. 1.

LOPEZ, G. A. C.; MILANO, S. Avaliação da durabilidade natural da madeira e de produtos usados na sua proteção. In: LEPAGE, E. S., (Coord.). Manual de Preservação de Madeiras. São Paulo: IPT, 1896. p. 473-510.

MARTINS, V. A.; ALVES, M. V. S.; SILVA, J. F.; REBELLO, E. R. G.; PINHO, G. S.C. Umidade de equilíbrio e risco de apodrecimento da madeira em condições de serviço no Brasil. Brasil

Florestal, n.76, p. 29-34, 2003.

MELO, R. R. de; STANGERLIN, D. M.; SANTINI, E. J.; HASELEIN, C. R.; GATTO, A. G.; SUSIN, F. Durabilidade natural da madeira de três espécies

Revista Árvore, Viçosa-MG, v.40, n.2, p.363-370, 2016 
florestais em ensaios de campo. Ciência Florestal, Santa Maria, v. 20, n. 2, p. 357-365, abr.-jun., 2010.

MORESCHI, J. C. Biodegradação da Madeira. Curitiba: UFPR, 1980, 38p.

OLIVEIRA, A. M. F.; LELIS, A. T. de; LEPAGE, E. S.; CARBALLEIRA LOPEZ, G. A.; OLIVIEIRA, L. C. S.; CAÑEDO, M. D.; MILANO, S. Agentes destruidores da madeira. In: LEPAGE, E.S.;OLIVEIRA, A. M. F.; LELIS, A. T. de; CARBALLEIRA LOPEZ, G. A.; CHIMELO, J. P.; OLIVIEIRA, L. C. S.; CAÑEDO, M. D.;

CAVALCANTE, M. S.; IELO, P. K. Y.; ZANOTTO, P. A.; MILANO, S. Manual de preservação de madeiras. São Paulo: IPT - Divisão de Madeiras, 1986. p. 99-278.

OLIVEIRA,J.T.S.Caracterização da madeira de eucalipto para a construção civil. 1997. Tese(Doutorado) Universidade de São Paulo, São Paulo, 1997.429 p.

PAES, J. B.; MELO, R. R.; LIMA, C. R. Resistência natual de sete madeiras a fungos e cupins xilófagos em condições de laboratório. Cerne, v. 13, p. 160-169, 2007.

SANTINI, E. J. Biodeterioração e preservação da madeira. Santa Maria: UFSM/CEPEF/FATEC, 1988. 125 p.

SCHEFFER, T.C., A climate index for estimating potential for decay in wood structures above ground. Forest Products Journal, v. 21, n. 10, p. 25-31, 1971.

TEXEIRA, D.E.; COSTA, A.F.; SANTANA, M.A.E. Aglomerado de bagaço de cana-de-açúcar: resistência natural aos apodrecedores.S cientiaForestalis, n.52,p.29-34,1997.

TREVISAN, H. Degradação natural de toras e sua influência nas propriedades físicas e mecânicas da madeira de cinco espécies florestais. 2006. Dissertação (Mestrado em Ciências

Florestais e Ambientais), Universidade Federal do Rio de Janeiro, Seropédica, 2006. 56 p.

TREVISAN, H.; CARVALHO, A. G.; TIEPPO, F. M. T. M.; LELIS, R. C. C. Avaliação de propriedades físicas e mecânicas da madeira de cinco espécies florestais em função da deterioração em dois ambientes. Revista Árvore, v.31, n.1, p.30-37, 2007.

TREVISAN, H.; MARQUES, F. M. T.; CARVALHO, A. G. Degradação natural de toras de cinco espécies florestais em dois ambientes. Floresta, v. 38, n. 1, jan./mar. p. 33-41, 2008.

WILLEITNER,H. Laboratory test sonthe natural durability of timber-methods and problems.Stockholm: The International Research Group on Wood Preservation, 1984. 11p.(Doc.IRG/WP/2217). 